Article

\title{
Growth, Secondary Metabolites and Enzyme Activity Responses of Two Edible Fern Species to Drought Stress and Rehydration in Northeast China
}

\author{
Yanlin Wang ${ }^{1,2,+}$ (D), Shanshan Gao ${ }^{1,2,+}$, Xingyuan $\mathrm{He}^{1,2,3}$, Yan $\mathrm{Li}^{1}$, Peiyang Li ${ }^{4}$, Yue Zhang ${ }^{1}$ \\ and Wei Chen $1,2,3, *$ \\ 1 Institute of Applied Ecology, Chinese Academy of Sciences, 72 Wenhua Road, Shenyang 110016, China; \\ wangyanlin1993@126.com (Y.W.); gaoshanliushui0908@163.com (S.G.); hexy@iae.ac.cn (X.H.); \\ liyan@iae.ac.cn (Y.L.); zhangyue4027@163.com (Y.Z.) \\ 2 University of Chinese Academy of Sciences, Beijing 101417, China \\ 3 Key Laboratory of Forest Ecology and Management, Chinese Academy of Sciences, Shenyang 110016, China \\ 4 Northest Yucai Bilingual School, Shenyang 110164, China; liyiqun7777@sina.com \\ * Correspondence: chenwei@iae.ac.cn; Tel.: +86-24-8397-0349 \\ + These authors contributed equally to this work.
}

Received: 13 February 2019; Accepted: 13 March 2019; Published: 16 March 2019

\begin{abstract}
The drought resistance mechanism of Matteuccia struthiopteris (L.) Todar. and Athyrium multidentatum (Doll.) Ching were measured under natural drought exposure. The results showed that the two edible fern species showed stronger resistance in the early stages of drought, mainly expressed as the decrease of relative leaf water content (RLWC), increase of osmotic substances, secondary metabolites such as flavonoids (FC), total phenols (TPC), proantho cyanidins (PCC) content and enzyme activity (superoxide dismutase (SOD), peroxidase (POD), catalase (CAT) and ascorbate peroxidase (APX)). The higher RLWC, FC, TPC, PCC and abscisic acid (ABA) content and lower $\mathrm{H}_{2} \mathrm{O}_{2}$ content indicates the stronger non-enzymatic antioxidant system and drought resistance of $A$. multidentatum. However, the proline (Pro) content changed slowly, and the synthesis of soluble protein (SP), total phenols, proantho cyanidins and ABA, SOD activity of two fern species were inhibited in the late stages of drought stress. This study can provide a scientific basis for the cultivation and utilization of edible fern species under forest in Northeast China.
\end{abstract}

Keywords: edible fern species; drought stress; rehydration; drought resistance; Northeast China

\section{Introduction}

Global warming has already led to frequent and extreme droughts in many areas [1,2]. The northeastern region of China is located in the middle and high latitudes of the northern hemisphere and is an important grain production base in China [3]. In recent years, the climate has been warming and drying in Northeast China. Since 1960, the drought and flood situation in the northeast has alternated, and the frequency of drought has gradually increased with the decadal changes [4], and the degree of drought has gradually increased. Moreover, the drought range is the largest and the intensity is strongest in summer [5].

Drought stress is one of the most serious abiotic stresses, which can lead to serious damage to plants including stomata closure, limitation of photosynthesis and inhibition of physiological functions such as antioxidant functions [6-8]. Under drought stress, plants will regulate the morphology, physiology and metabolism to adapt to a water deficit environment [9]. Generally, plants accumulate osmotic substances such as soluble sugars (SS), soluble proteins (SP) and proline (Pro) to regulate water potential and encourage plants to absorb more water from the environment to maintain normal 
physiological functions [10]. Moreover, Pro not only regulates water potential as an osmotic regulator, but also participates in other physiological responses, such as ROS-scavenging, antioxidant metabolism, etc. [11]. Malondialdehyde (MDA) is the end product of membrane lipid peroxidation, so MDA is considered as an indicator of drought stress. Usually, the MDA content will increase as soil water content decreases [6,12-14].

Under drought stress, plant cells will produce ROS including $\mathrm{H}_{2} \mathrm{O}_{2}, \mathrm{O}_{2}{ }^{-}$, etc., which can lead to membrane lipid peroxidation, damage of DNA and intracellular protein, and ultimately destroy the structure and function of the cell membrane $[15,16]$. Plants can scavenge ROS through the antioxidant system, which includes the enzymatic antioxidant system and non-enzymatic antioxidant system. The enzymatic antioxidant system include superoxide dismutase (SOD), peroxidase (POD), catalase (CAT), ascorbate peroxidase (APX), glutathione reductase (GR) and the non-enzymatic antioxidant system includes some secondary metabolites such as flavonoids and phenols $[6,17]$.

ABA in plants was significantly correlated with soil moisture content, which plays a pivotal role in drought resistance [18]; leaf stomatal conductance and growth rate were negatively correlated with ABA concentration in the aerial part of plants [19]. ABA can effectively regulate stomatal closure and reduce transpiration, therefore, $\mathrm{ABA}$ content is positively correlated with drought resistance of plants [20,21]. In addition, ABA can increase the activity of antioxidant system and improve the efficiency in ROS scavenging [22].

At present, drought resistance studies have been carried out on some fern species. The growth traits of Adiantum reniforme L. var. sinensis Y. X. Lin and Adiantum capillus-veneris L. were significantly affected by drought stress, and A. reniforme var. sinensis has relatively high drought tolerance [23]. Similarly, the drought resistance of Adiantum flabellulatum L. is stronger than that of A. capillus-veneris [22]. The growth and photosynthetic traits of Adiantum pedatum L., Pteridium aquilinum L. Kuhn var. latiusculum (Desy.) Underw. ex Heller, Dryopteris erythrosora (Eat.) O. Ktze. and Lepisorus thunbergianus (Kaulf.) Ching were studied under drought stress, and the results showed that L. thunbergianus has high adaptation to water deficits [24]. Furthermore, the drought tolerance of some other fern species was studied [25-29].

Matteuccia struthiopteris (L.) Todar. and Athyrium multidentatum (Doll.) Ching are common edible fern species and traditional medicine [30,31], which are distributed in Northeast China [32]. The two fern species grow in the moist place under the forest. The two fern species have many pharmacological effects, such as detoxification, antiviral and blood pressure regulation [31,33]. What is more, the two fern species are popular as wild vegetables in Northeast China, Japan, the United States and Canada $[30,31]$. Due to the edible and medical value of the two fern species, they are harvested and processed in many areas. At present, artificial planting of these two fern species has begun in Northeast China, and higher soil moisture favors the growth of the two fern species $[34,35]$. However, the drought resistance and irrigation strategy of the two fern species under artificial cultivation are unknown. In this study, growth traits, physiology, and secondary metabolites were analyzed in relation to drought resistance. This research attempts to reveal the mechanisms according to the physiological and metabolic responses of two fern species to drought stress and after rehydration, and to compare the drought resistance of the two fern species in order to provide a scientific basis for the exploitation, cultivation and utilization of edible fern species under forest in Northeast China.

\section{Materials and Methods}

\subsection{Plant Materials}

Two edible fern species including M. struthiopteris and A. multidentatum (three-year-old rhizomes) were planted in pots (caliber $21 \mathrm{~cm} \times$ depth $14 \mathrm{~cm}$ ). The pots were filled with turfy soil and sand mixed at a volume ratio of $3: 1(v / v)$, the organic matter content was $52 \%$, and the N:P:K was 23:4:8. Plants were irrigated every 2 days before drought stress treatment. After the plants were growing well, fern species with same height and good growth were selected for experimental study. 


\subsection{Experiment and Stress Treatment}

The experiment was carried in the Arboretum $\left(41^{\circ} 46^{\prime} \mathrm{N}, 123^{\circ} 27^{\prime} \mathrm{E}\right)$ of the Institute of Shenyang Applied Ecology, Chinese Academy of Sciences, China. The two fern species were placed under a canopy in a natural environment. Twenty-five of the two fern species were amply watered and then the irrigation was stopped, and the plants were exposed to the gradually drying soil environment after 1 day. The plants watered for 1 day were used as plant materials of day 0 . Five pots were randomly selected for the measurement of growth indexes and three pots were randomly selected for the measurement of physiological indexes every 5 days, rehydration was conducted at day 20 and various indexes of plants were determined at day 21 after rehydration. TDR 200 Soil Moisture Sensor was used to monitor soil moisture, the soil moisture content was $31 \%, 17 \%, 8 \%, 5 \%, 2 \%$ at day $0,5,10$, 15 and 20 of drought exposure, respectively, and then rose to $34 \%$ after rehydration.

\subsection{Growth Traits}

Five leaves were collected from each plant, the fresh weight (FW) was weighed, and the leaf area (LA) was measured according to the description of Xiao et al. [36]. The specific leaf area (SLA) was calculated as leaf area per dry weight $\left(\mathrm{cm}^{2} \mathrm{~g}^{-1}\right)$. The leaves were weighed (FW) and placed in distilled water for $8 \mathrm{~h}$, the total weight (TW) was weighed, then the leaves were put in paper bags and dried at $105^{\circ} \mathrm{C}$ for $30 \mathrm{~min}$, then dried at $80^{\circ} \mathrm{C}$ to a constant weight, and the dry weight (DW) was recorded. The relative leaf water content (RLWC) was calculated according to Li et al. [37] using the formula: $\operatorname{RLWC}(\%)=[(\mathrm{FW}-\mathrm{DW}) /(\mathrm{TW}-\mathrm{DW})] \times 100$.

\subsection{Hydrogen Peroxide $\left(\mathrm{H}_{2} \mathrm{O}_{2}\right)$, Malondialdehyde (MDA) Content and Ion Leakage (IL)}

The $\mathrm{H}_{2} \mathrm{O}_{2}$ concentration was measured as described by Mukherjee and Choudhuri [38]. Leaf samples $(0.2 \mathrm{~g})$ were ground in liquid nitrogen, extracted in ice-cold acetone, then centrifuged at $12,000 \mathrm{rpm}$ for $20 \mathrm{~min}$ at $4{ }^{\circ} \mathrm{C}$. The extracted solution $(1 \mathrm{~mL})$ was mixed with $0.1 \mathrm{~mL} 10 \%$ titanium chloride in $\mathrm{HCl}, 0.2 \mathrm{~mL}$ strong ammonia. After precipitate was formed, the mixture was centrifuged at 10,000 rpm for $10 \mathrm{~min}$. The precipitate was washed repeatedly with acetone 3 to 5 times until the plant pigments were removed. $\mathrm{H}_{2} \mathrm{SO}_{4}\left(2 \mathrm{~mol} \mathrm{~L}^{-1} 10 \mathrm{~mL}\right)$ was added to the precipitate after washing. When the precipitate was dissolved completely, the solution was used to measure the $\mathrm{H}_{2} \mathrm{O}_{2}$ content at $415 \mathrm{~nm}$ by using UV-1800 spectrophotometer (Shimadzu, Kyoto, Japan).

The MDA concentration as the marker of lipid peroxidation was determined as described by Heath and Packer [39] with modifications. Leaf samples ( $0.2 \mathrm{~g})$ were powdered with liquid nitrogen and homogenized with $5 \mathrm{~mL} 20 \%$ TCA. The mixture was centrifuged at $7000 \mathrm{rpm}$ for $10 \mathrm{~min}$ and the supernatant was taken. Two milliliters of $20 \%$ TCA containing $0.5 \%$ thiobarbituric acid (TBA) was added to the supernatant and heated in a $100{ }^{\circ} \mathrm{C}$ water bath for $15 \mathrm{~min}$ and then rapidly cooled down in crushed ice. After centrifugation at 10,000 rpm for $10 \mathrm{~min}$, the absorbance of the supernatant was measured at $450 \mathrm{~nm}, 532 \mathrm{~nm}$ and $600 \mathrm{~nm}$ by using a UV-1800 spectrophotometer (Shimadzu, Kyoto, Japan).

Ion leakage (IL) of leaves was measured as described by Liu et al. [40] with modifications. Leaves $(0.2 \mathrm{~g})$ from different plants were placed into test tubes, and $50 \mathrm{~mL}$ distilled water was added. The test tubes were stood for $8 \mathrm{~h}$ before measuring the electrical conductivity (S1). The test tubes were placed in a boiling water bath for $15 \mathrm{~min}$ and then cooled to room temperature, and the electrical conductivity was measured (S2). At the same time, the electrical conductivity of distilled water was measured (S3). The IL formula is as follows: IL $(\%)=(\mathrm{S} 1-\mathrm{S} 3) /(\mathrm{S} 2-\mathrm{S} 1) \times 100$.

\subsection{Osmotic Regulators}

Soluble protein (SP) was determined according the method of Marion [41]. Leaf samples ( $0.2 \mathrm{~g})$ were powdered with liquid nitrogen and homogenized with $5 \mathrm{~mL} 0.05 \mathrm{~mol} \mathrm{~L}^{-1}$ phosphate buffer $(\mathrm{pH}$ $=7.8)$, and then centrifuged at $3000 \mathrm{rpm}$ for $10 \mathrm{~min}$. Supernatant $(1 \mathrm{~mL})$ and coomassie brilliant blue 
$(5 \mathrm{~mL})$ were added to a $10 \mathrm{~mL}$ centrifuge tube for $2 \mathrm{~min}$, then the absorbance of the reaction mixture was measured at $595 \mathrm{~nm}$ by using a UV-1800 spectrophotometer (Shimadzu, Kyoto, Japan).

Proline (Pro) was extracted and measured as described by Irigoyen et al. [42] with modifications. Leaf samples $(0.5 \mathrm{~g})$ were placed in a large test tube, and $3 \% 5 \mathrm{~mL}$ sulfosalicylic acid solution was added, and extracted was heated in a boiling water bath for $10 \mathrm{~min}$ (shaken frequently during the extraction process). After cooling, the mixture was filtered in a clean test tube, and the filtrate was the extract of Pro. Extracts $(2 \mathrm{~mL})$ were transferred into a centrifuge tube with a lid, $2 \mathrm{~mL}$ glacial acetic acid and $2 \mathrm{~mL} \mathrm{2.5 \%} \mathrm{ninhydrin} \mathrm{were} \mathrm{added,} \mathrm{and} \mathrm{then} \mathrm{the} \mathrm{centrifuge} \mathrm{tubes} \mathrm{with} \mathrm{reaction} \mathrm{solution} \mathrm{were}$ heated in a boiling water bath for $30 \mathrm{~min}$. After cooling, $4 \mathrm{~mL}$ of toluene was added. The sample was shaken for $30 \mathrm{~s}$ and stood for a while, and the upper layer was taken and centrifuged for $5 \mathrm{~min}$ at $3000 \mathrm{rpm}$. The upper layer of the Pro red toluene solution was taken to measure the absorbance at $520 \mathrm{~nm}$ by using a UV-1800 spectrophotometer (Shimadzu, Kyoto, Japan).

The ABA Elisa kit (ZC BIO ZC-53364) (http:/ / www.zcibio.com) was used to measure the ABA content. Leaf samples $(0.2 \mathrm{~g})$ were ground in liquid nitrogen, $1 \mathrm{~mL} 80 \%$ methanol was added and was set at $-20^{\circ} \mathrm{C}$ overnight. The extract was centrifuged for $20 \mathrm{~min}$ at $4{ }^{\circ} \mathrm{C}, 8000 \mathrm{rpm}$. The supernatant was passed through a C-18 solid phase extraction column. After passing through the column, the sample was vacuum dried. Phosphate buffer $(\mathrm{pH}=7.41 \mathrm{~mL})$ was added into the tube containing sample and mixed, and stood at room temperature for $30 \mathrm{~min}$, which was centrifuged at $4{ }^{\circ} \mathrm{C}, 8000 \mathrm{rpm}$ for $15 \mathrm{~min}$. The supernatant was stored at $4{ }^{\circ} \mathrm{C}$ for determining ABA content by using a Microplate reader (InterMed, South Portland, ME, USA). Standard curves and calculation formulas were provided in the kit instructions.

\subsection{Secondary Metabolites}

Secondary metabolites were determined according to Ali et al., Sarker and Oba, and Zhang et al. [43-45]. The samples were dried to constant weight, pulverized, and passed through a 40 mesh sieve. About $0.1 \mathrm{~g}$ dry sample was weighed to extract secondary metabolites by using $60 \%$ ethanol. Extraction was performed using ultrasonic extraction, and the power was $300 \mathrm{~W}$ and the temperature was $60^{\circ} \mathrm{C}$. After extracting for $30 \mathrm{~min}$, centrifugation at $12,000 \mathrm{rpm}$ at $25^{\circ} \mathrm{C}$ for $10 \mathrm{~min}$, the extraction was used to test these three indexes by using a Microplate reader (InterMed, South Portland, ME, USA). The reagents from a biochemical kit (ZCI BIO ZC-S0358, ZC-S0356, ZC-S0357) (http:/ / www.zcibio.com) were used to determine Proantho cyanidins, flavonoids and total phenols content. Standard curves and calculation formulas were provided in the kit instructions.

\subsection{Antioxidant Enzyme Activities}

Leaf samples $(0.2 \mathrm{~g})$ were powdered with liquid nitrogen and ground with $5 \mathrm{~mL} 0.05 \mathrm{~mol} \mathrm{~L}^{-1}$ phosphate buffer ( $\mathrm{pH}=7.8$ ). The mixture was centrifuged at $8000 \mathrm{rpm}$ at $4{ }^{\circ} \mathrm{C}$ for $15 \mathrm{~min}$, and the supernatant was used to analyze the CAT, POD and SOD activities. The CAT activity was measured as described by Azevedo et al. [46]. The reaction mixture contained $0.05 \mathrm{~mol} \mathrm{~L}^{-1}$ phosphate buffer ( $\mathrm{pH}=7.8$ ) and $0.1 \mathrm{~mol} \mathrm{~L}^{-1} \mathrm{H}_{2} \mathrm{O}_{2}$, distilled water and enzyme extract was used to measure the CAT activity at $240 \mathrm{~nm}$ by using a UV-1800 spectrophotometer (Shimadzu, Kyoto, Japan). One unit of CAT was defined as the amount of enzyme that reduced by 0.1 under $A_{240}$ in $1 \mathrm{~min}$. The POD activity was measured as described by Zhou and Leul [47] with some modifications. The reaction mixture included $0.05 \mathrm{~mol} \mathrm{~L}^{-1}$ phosphate buffer $(\mathrm{pH}=7.0), 0.2 \%(v / v)$ guaiacol and $30 \% \mathrm{H}_{2} \mathrm{O}_{2}$. The enzyme extract was added to reaction mixture $(3 \mathrm{~mL})$, and the mixture was used to measure POD activity at $470 \mathrm{~nm}$ by using a UV-1800 spectrophotometer (Shimadzu, Kyoto, Japan). One unit of POD was defined as 0.01 absorbance increase per minute at $470 \mathrm{~nm}$. The SOD activity was measured as described by Giannopolitis and Ries [48]. The reaction system included $0.05 \mathrm{~mol} \mathrm{~L}^{-1}$ phosphate buffer, $130 \mathrm{mmol}$ $\mathrm{L}^{-1}$ methionine, $630 \mu \mathrm{mol} \mathrm{L}{ }^{-1} \mathrm{NBT}$, enzyme extract and $13 \mu \mathrm{mol} \mathrm{L}^{-1}$ riboflavin. The SOD activity was measured at $560 \mathrm{~nm}$ by using a UV-1800 spectrophotometer (Shimadzu, Kyoto, Japan). One unit of SOD was defined as the amount of enzyme added by $50 \%$ inhibition of NBT reduction. 
The APX was measured according to Nakano and Asada [49]. Leaf samples $(0.2 \mathrm{~g})$ were powdered with liquid nitrogen and ground with $3.5 \mathrm{~mL} 0.1 \mathrm{~mol} \mathrm{~L}^{-1}$ phosphate buffer $(\mathrm{pH}=7.0)$ containing $1 \mathrm{mmol} \mathrm{L}^{-1}$ EDTA, $1 \mathrm{mmol} \mathrm{L}^{-1}$ ascorbic acid (ASA), $4 \% \mathrm{PVP}$ and $0.25 \%$ Triton X-100, the mixture was transferred into a centrifuge tube, then, $1.5 \mathrm{~mL}$ saturated $\left(\mathrm{NH}_{4}\right)_{2} \mathrm{SO}_{4}$ was added and the centrifuge tube was shaken well. The mixture was centrifuged at $13,000 \mathrm{rpm}$, at $4{ }^{\circ} \mathrm{C}$ for $20 \mathrm{~min}$, and the supernatant was taken. The reaction mixture containing $0.05 \mathrm{mmol} \mathrm{L}^{-1} \mathrm{ASA}, 2 \mathrm{mmol} \mathrm{L}^{-1} \mathrm{H}_{2} \mathrm{O}_{2}$ and enzyme extract was used to analyze the APX activity at $290 \mathrm{~nm}$ by using a UV-1800 spectrophotometer (Shimadzu, Kyoto, Japan). One unit of APX was defined as the amount of enzyme that oxidizes $1 \mu \mathrm{mol}$ of ASA per minute at room temperature (extinction coefficient $2.8 \mathrm{mM}^{-1} \mathrm{~cm}^{-1}$ ).

\subsection{Statistical Analysis}

All the data were analyzed with Microsoft Excel 2016 and SPSS 22.0 software, graphs were edited with GraphPad Prism 5 software. The data were statistically analyzed by the ANOVA program in SPSS 22. Comparisons of the means used the least significant difference (LSD) at $p \leq 0.05$. The data in the chart is the mean \pm standard deviation.

\section{Results}

\subsection{Growth Traits}

The RLWC of M. struthiopteris and A. multidentatum decreased slowly to $91.48 \%$ and $92.10 \%$ at $5 \%$ soil moisture, respectively, and then at $2 \%$ soil moisture, the RLWC fell sharply to $79.76 \%$ and $83.14 \%$, respectively. After rehydration, the RLWC rose to $94.22 \%$ and $93.34 \%$, respectively (Figure 1A).
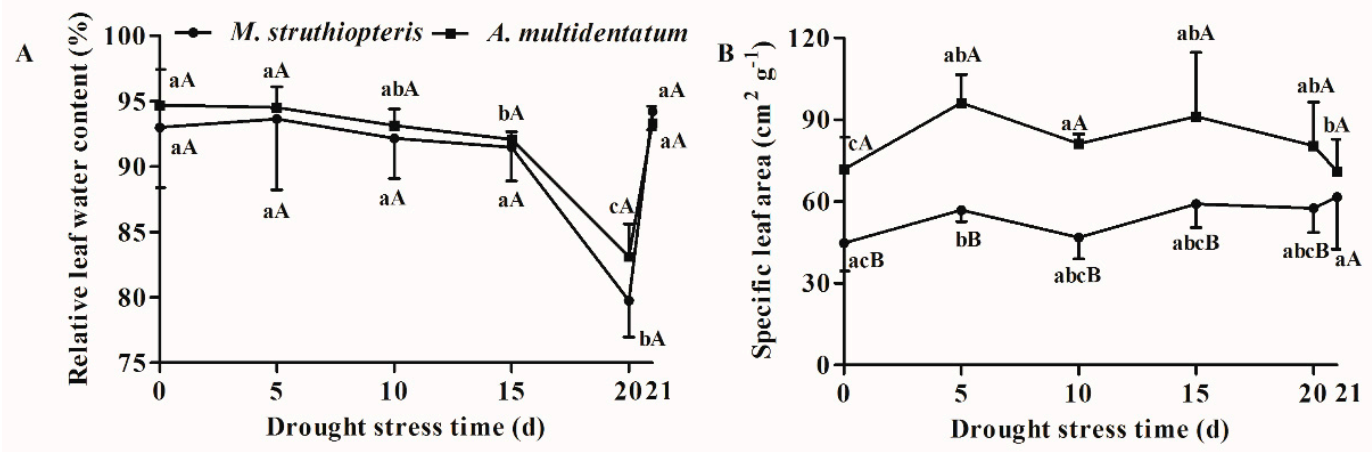

Figure 1. Effects of drought stress and rehydration on relative leaf water content (RLWC) and specific leaf area (SLA) of two fern species. (A) RLWC; (B) SLA. Different small letters mean a significant difference among different treatments in the same fern at $p \leq 0.05$ level. Different big letters mean a significant difference between the two fern species at $p \leq 0.05$ level. Error bars are $\pm \operatorname{SD}(n=5)$.

The change in SLA of the two fern species is shown in Figure 1B. The SLA of M. struthiopteris showed an upward trend. The SLA increased by $12 \%$ at $2 \%$ of soil moisture compared to the SLA at $31 \%$ of soil moisture. However, the change in the SLA of A. multidentatum is complicated, the SLA at $2 \%$ of soil moisture increased by $8 \%$ compared to the SLA at $31 \%$ of soil moisture. After rehydration, the SLA of $M$. struthiopteris increased by $4 \%$, while the SLA of A. multidentatum decreased by $9 \%$ compared to the SLA at $2 \%$ of soil moisture. The SLA of $M$. struthiopteris was significantly higher than A. multidentatum $(p \leq 0.05)$.

\section{2. $\mathrm{H}_{2} \mathrm{O}_{2}, \mathrm{MDA}$ Content and IL}

The $\mathrm{H}_{2} \mathrm{O}_{2}$ content of $M$. struthiopteris increased during drought stress, and continued to increase to the maximum $\left(1.55 \mu \mathrm{mol} \mathrm{g}{ }^{-1} \mathrm{FW}\right)$ after rehydration. However, the $\mathrm{H}_{2} \mathrm{O}_{2}$ content of A. multidentatum reached the maximum $\left(0.29 \mu \mathrm{mol} \mathrm{g}^{-1} \mathrm{FW}\right)$ at $5 \%$ of soil moisture and then decreased (Figure $\left.2 \mathrm{~A}\right)$. The $\mathrm{H}_{2} \mathrm{O}_{2}$ content of $A$. multidentatum was significantly higher than $M$. struthiopteris except at $31 \%$ 
and $5 \%$ of soil moisture. The MDA content of $M$. struthiopteris increased from 6.68 to $20.16 \mu \mathrm{mol} \mathrm{g}{ }^{-1}$ FW, and then decreased to $9.71 \mu \mathrm{mol} \mathrm{g}^{-1} \mathrm{FW}$ after rehydration. However, the MDA content of $A$. multidentatum reached its maximum $\left(29.65 \mu \mathrm{mol} \mathrm{g}^{-1} \mathrm{FW}\right)$ at $17 \%$ of soil moisture, and then increased from 14.39 ( $8 \%$ of soil moisture) to $28.26 \mu \mathrm{mol} \mathrm{g}^{-1} \mathrm{FW}$ ( $2 \%$ of soil moisture). After rehydration, it decreased to $22.00 \mu \mathrm{mol} \mathrm{g}^{-1} \mathrm{FW}$ (Figure 2B). In addition, the MDA content of A. multidentatum was significantly higher than $M$. struthiopteris $(p \leq 0.05)$ except at $8 \%$ of soil moisture. The IL showed similar variation (Figure 2C). The IL reached their maximum (29.47\% and 33.31\%) when the soil moisture dropped to $2 \%$, respectively. Then the IL decreased after rehydration.
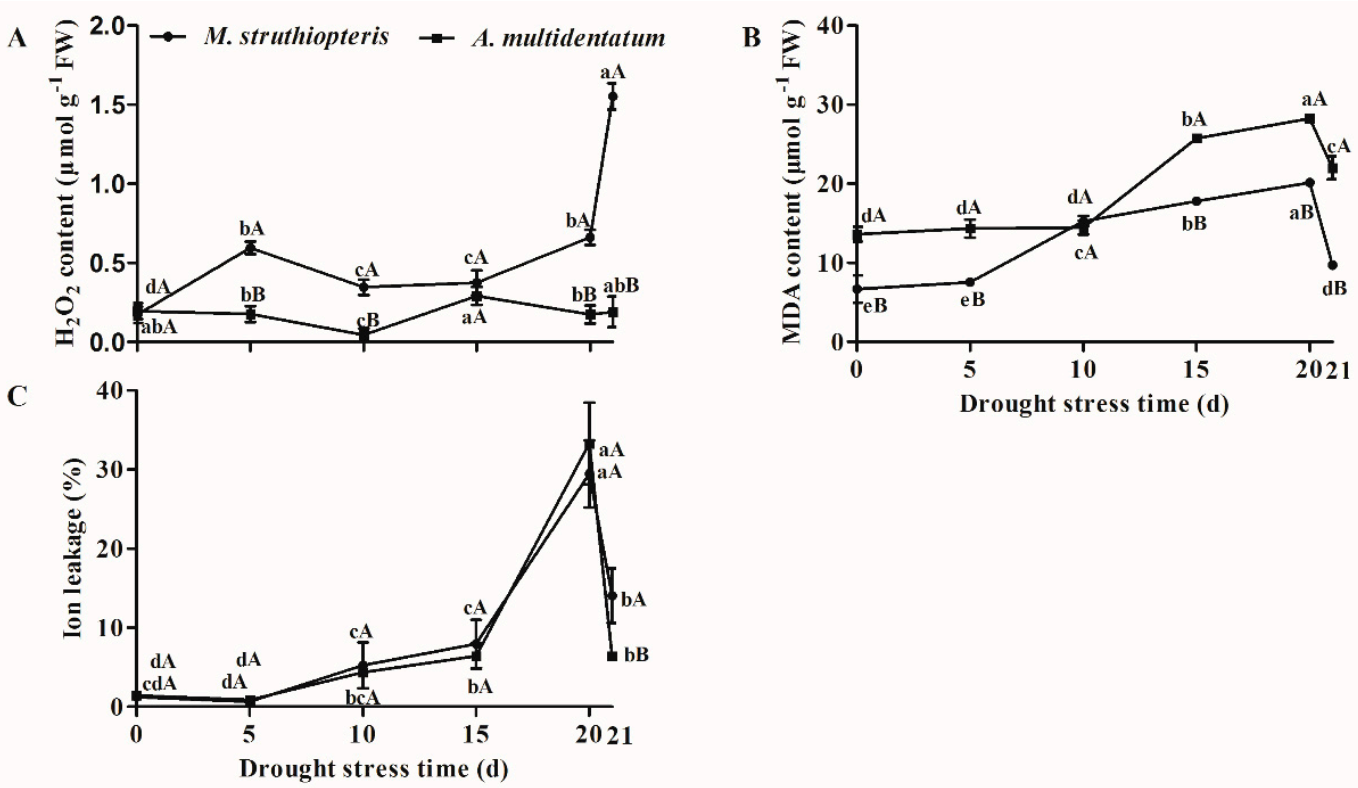

Figure 2. Effects of drought stress and rehydration on $\mathrm{H}_{2} \mathrm{O}_{2}$, malondialdehyde (MDA) content and ion leakage (IL) of two fern species. (A) $\mathrm{H}_{2} \mathrm{O}_{2}$ content; (B) MDA content; (C) IL. Different small letters mean a significant difference among different treatments in the same fern at $p \leq 0.05$ level. Different big letters mean a significant difference between the two fern species at $p \leq 0.05$ level. In (Figure 2B), the significant mark of M. struthiopteris is on the upper side, and the significant mark of A. multidentatum is on the lower side. In (Figure 2C), the significant mark of $M$. struthiopteris is on the lower side, and the significant mark of $A$. multidentatum is on the upper side. Error bars are $\pm \operatorname{SD}(n=3,3$ and 5).

\subsection{Osmotic Regulators}

The SP of M. struthiopteris and A. multidentatum showed same trend (Figure 3A), which reached their maximum $\left(1.75 \mathrm{mg} \mathrm{g}^{-1} \mathrm{FW}\right)$ at $17 \%$ of soil moisture and $8 \%$ of soil moisture $\left(1.66 \mathrm{mg} \mathrm{g}^{-1} \mathrm{FW}\right)$ during the exposure to drought stress, respectively, and then decreased until rehydration. The SP of the two fern species increased to 1.66 and $1.73 \mathrm{mg} \mathrm{g}^{-1} \mathrm{FW}$ after rehydration, respectively. However, the Pro content did not express an obvious change except for the SP content at $2 \%$ of soil moisture. The maximum values of Pro content of the two fern species were reached at $2 \%$ of soil moisture $(21.12$ and $19.21 \mathrm{mg} \mathrm{g}^{-1} \mathrm{FW}$ ) and then decreased after rehydration (Figure 3B).

In the early stages ( $31 \%$ of soil moisture) of drought exposure, the ABA content of M. struthiopteris was $577.4 \mathrm{ng} \mathrm{g}^{-1}$, and then decreased. There were no differences at $17 \%, 8 \%$ and $5 \%$ of soil moisture and rehydration ( $34 \%$ of soil moisture), but the ABA content at $2 \%$ of soil moisture was significantly lower than others $(p \leq 0.05)$. However, the ABA content of $A$. multidentatum reached the maximum $\left(564.5 \mathrm{ng} \mathrm{g}^{-1}\right)$ when the soil moisture was $8 \%$, but there were no significant differences at $31 \%, 17 \%$, $8 \%$ and $5 \%$ of soil moisture. The minimum ABA content $\left(41.02 \mathrm{ng} \mathrm{g}^{-1}\right)$ appeared when the soil moisture dropped to $2 \%$, and then increased after rehydration (Figure 3C). The ABA content of $A$. multidentatum was significantly higher than M. struthiopteris $(p \leq 0.05)$ except at $31 \%$ of soil moisture and after rehydration. 

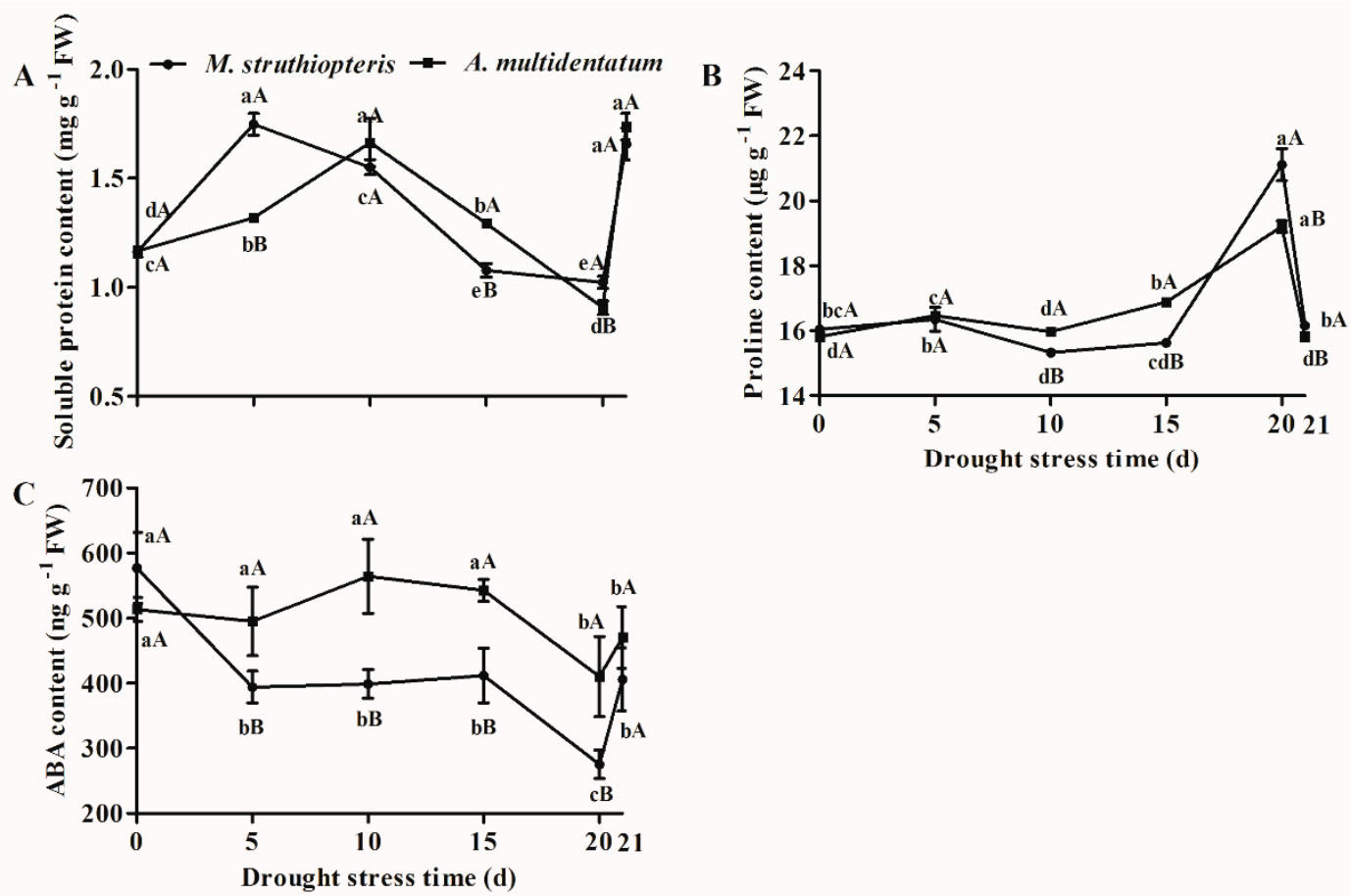

Figure 3. Effects of drought stress and rehydration on soluble protein and proline content of two fern species. (A) Soluble protein (SP) content; (B) proline (Pro) content; (C) abscisic acid (ABA) content. Different small letters mean a significant difference among different treatments in the same fern at $p \leq 0.05$ level. Different big letters mean a significant difference between the two fern species at $p \leq 0.05$ level. Error bars are $\pm \operatorname{SD}(n=3)$.

\subsection{Secondary Metabolites}

The FC of M. struthiopteris reached the maximum $\left(9.40 \mathrm{mg} \mathrm{g}^{-1} \mathrm{FW}\right)$ at $17 \%$ of soil moisture, and then increased from 6.53 ( $8 \%$ of soil moisture) to $9.48 \mathrm{mg} \mathrm{g}^{-1} \mathrm{FW}$ after rehydration. The FC of A. multidentatum increased from 5.74 ( $31 \%$ of soil moisture) to $12.23 \mathrm{mg} \mathrm{g}^{-1} \mathrm{FW}$ after rehydration (Figure 4A). Furthermore, the FC of $A$. multidentatum was significantly higher than $M$. struthiopteris when the soil moisture was $8 \%, 5 \%, 2 \%$ and $34 \%$ (rehydration) $(p \leq 0.05)$. The TPC of $M$. struthiopteris reached the maximum $\left(0.62 \mathrm{mg} \mathrm{g}^{-1} \mathrm{FW}\right)$ when the soil moisture was $2 \%$. There were no significant differences among $31 \%, 17 \%$ and $8 \%$ of soil moisture. After rehydration, the TPC decreased to the same level of $31 \%, 17 \%$ and $8 \%$ of soil moisture. However, the TPC of A. multidentatum increased from 0.39 ( $31 \%$ of soil moisture) to $0.63 \mathrm{mg} \mathrm{g}^{-1} \mathrm{FW}$ ( $5 \%$ of soil moisture), and then decreased, but turned to increase again after rehydration (Figure 4B). Otherwise, the TPC of A. multidentatum at $17 \%$ and $8 \%$ of soil moisture was significantly higher than $M$. struthiopteris $(p \leq 0.05)$. The PCC of $M$. struthiopteris increased from 1.63 (31\% of soil moisture) to $3.47 \mathrm{mg} \mathrm{g}^{-1} \mathrm{FW}$ ( $5 \%$ of soil moisture), and then decreased, while the PCC of A. multidentatum had the minimum ( $\left.1.91 \mathrm{mg} \mathrm{g}^{-1} \mathrm{FW}\right)$ at $31 \%$ of soil moisture, and kept at a higher level afterwards (Figure 4C). The PCC of A. multidentatum was higher than M. struthiopteris except at $8 \%$ and $5 \%$ of soil moisture. 
A
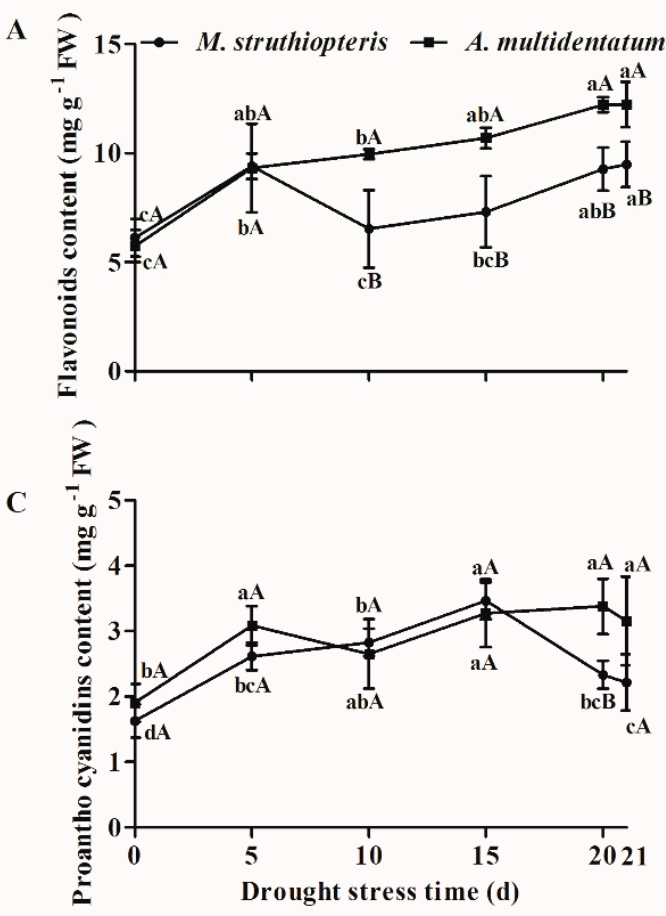

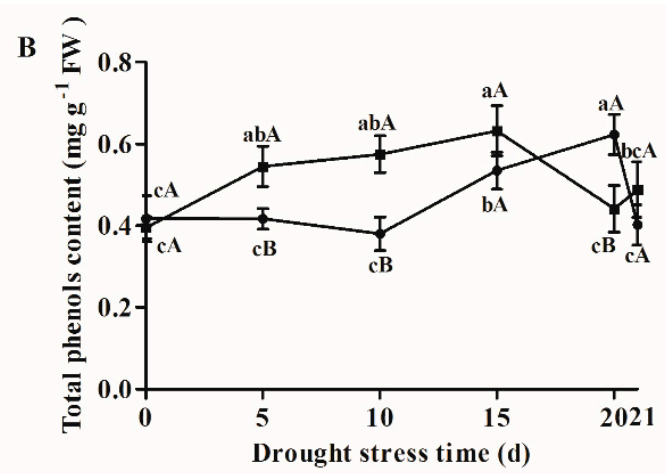

Figure 4. Effects of drought stress and rehydration on flavonoids, total phenols content and Proantho cyanidins content of two fern species. (A) Flavonoids content (FC); (B) total phenols content (TPC); (C) Proantho cyanidins content (PCC). Different small letters mean a significant difference among different treatments in the same fern at $p \leq 0.05$ level. Different big letters mean a significant difference between the two fern species at $p \leq 0.05$ level. Error bars are $\pm \mathrm{SD}(n=3)$.

\subsection{Antioxidant Enzyme Activities}

The SOD activity of two fern species increased to the maximum $\left(6.29 \times 10^{6}\right.$ and $6.33 \times 10^{6} \mathrm{U}$ $\left.\mathrm{g}^{-1} \mathrm{~h}^{-1} \mathrm{FW}\right)$ at $8 \%$ of soil moisture, respectively, and then decreased to the minimum $\left(1.03 \times 10^{6}\right.$ and $0.45 \times 10^{6} \mathrm{U} \mathrm{g}^{-1} \mathrm{~h}^{-1} \mathrm{FW}$ ) after rehydration (Figure 5A). The POD activity of $M$. struthiopteris decreased from $8.72 \times 10^{2} \mathrm{U} \mathrm{g}^{-1} \mathrm{~min}^{-1} \mathrm{FW}$ ( $31 \%$ of soil moisture) to $6.25 \times 10^{2} \mathrm{U} \mathrm{g}^{-1} \mathrm{~min}^{-1} \mathrm{FW}$ ( $5 \%$ of soil moisture), and then increased to the maximum $\left(11.10 \times 10^{2} \mathrm{U} \mathrm{g}^{-1} \mathrm{~min}^{-1} \mathrm{FW}\right)$ after rehydration. However, the POD activity of $A$. multidentatum decreased from $8.32 \times 10^{2} \mathrm{U} \mathrm{g}^{-1} \mathrm{~min}^{-1} \mathrm{FW}$ ( $31 \%$ of soil moisture) to $5.00 \times 10^{2} \mathrm{U} \mathrm{g}^{-1} \mathrm{~min}^{-1} \mathrm{FW}$ (17\% of soil moisture), and then increased to the maximum $\left(12.26 \times 10^{2} \mathrm{U} \mathrm{g}^{-1} \mathrm{~min}^{-1} \mathrm{FW}\right)$ when the soil moisture dropped to $2 \%$. After rehydration, the POD activity of A. multidentatum decreased (Figure 5B). The CAT activity of $M$. struthiopteris increased to the maximum (13.39 $\left.\mathrm{U} \mathrm{g}^{-1} \mathrm{~min}^{-1} \mathrm{FW}\right)$ at $8 \%$ of soil moisture, and then continued to decline. The trend of the CAT activity of $A$. multidentatum was similar to POD activity, which decreased to the minimum (8.32 $\left.\mathrm{U} \mathrm{g}^{-1} \mathrm{~min}^{-1} \mathrm{FW}\right)$ at $17 \%$ of soil moisture, and then increased to the maximum $\left(17.36 \mathrm{U} \mathrm{g}^{-1}\right.$ $\left.\mathrm{min}^{-1} \mathrm{FW}\right)$ at $2 \%$ of soil moisture. The CAT activity of $A$. multidentatum decreased once again after rehydration (Figure 5C). The APX activity of $M$. struthiopteris reached its maximum when the soil moisture was $2 \%$, and then decreased after rehydration. The APX activity of A. multidentatum at $5 \%$ of soil moisture was significantly higher than the others $(p \leq 0.05)$, although which increased a little after rehydration compared to the APX activity at $2 \%$ of soil moisture (Figure $5 \mathrm{D}$ ). 
A
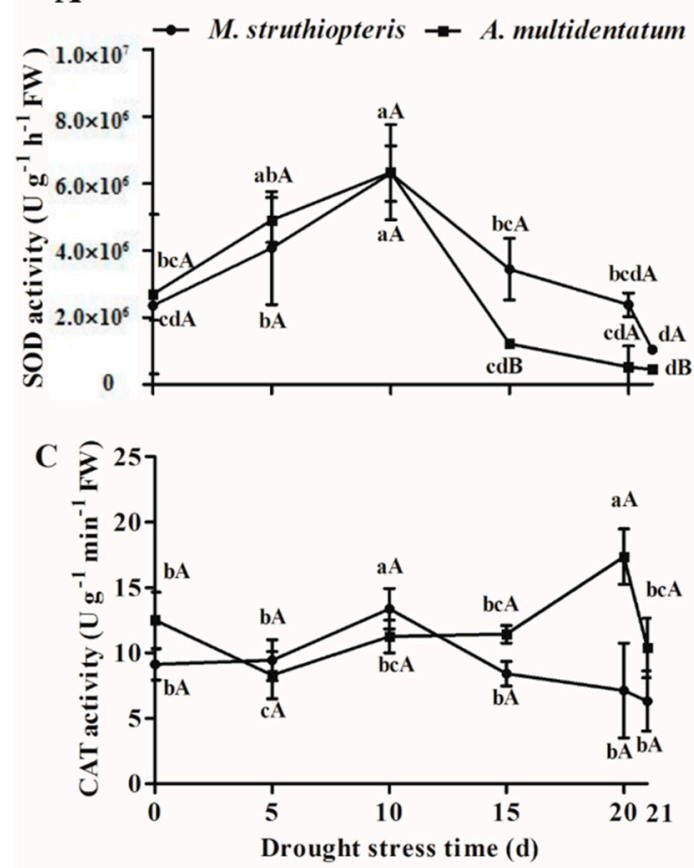

B

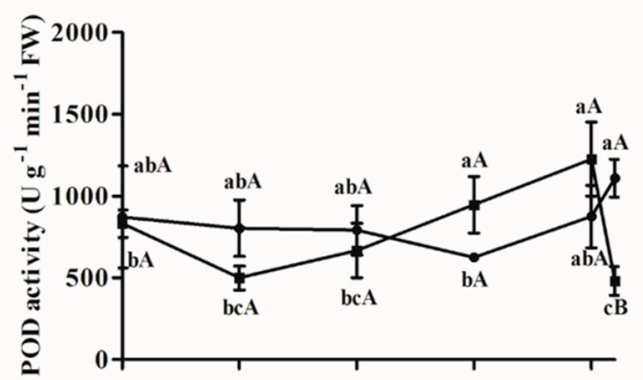

D

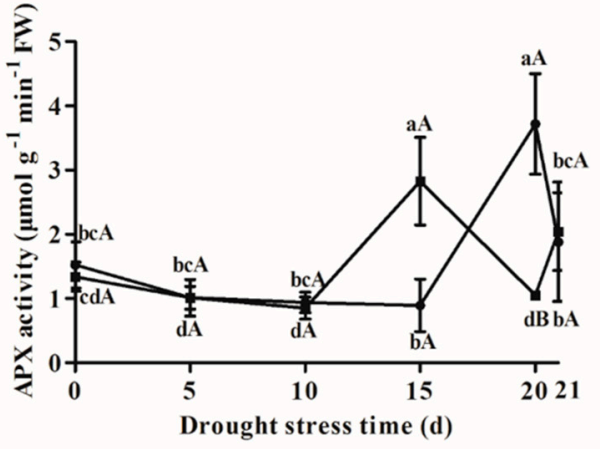

Figure 5. Effects of drought stress and rehydration on antioxidant enzyme activities of two fern species. (A) superoxide dismutase (SOD) activity; (B) peroxidase (POD) activity; (C) catalase (CAT) activity; (D) ascorbate peroxidase (APX) activity. Different small letters mean a significant difference among different treatments in the same fern at $p \leq 0.05$ level. Different big letters mean a significant difference between the two fern species at $p \leq 0.05$ level. Error bars are $\pm \operatorname{SD}(n=3)$.

\section{Discussion}

Drought stress has a lot of negative effects on plants, such as inhibiting photosynthesis and growth, destroying the stability of membranes and leading to a series of physiological reactions [50-53]. In addition, severe drought stress can cause plant deaths and crop yield reduction [15,54]. Previous studies have focused on crops, ornamental plants, etc. $[10,15,51,53]$, however, little research has been done on the drought resistance of wild vegetables. M. struthiopteris and A. multidentatum as important wild vegetables and Chinese medicine in Northeast China, are sensitive to water condition $[35,55]$. Thus, understanding the drought resistance of these two fern species is important for the cultivation, management and utilization.

\subsection{The Responses of Growth Traits to Drought Stress}

Phenotypic plasticity is crucial in plants' responses to environment stress [56,57]. The plasticity of plants is negatively correlated with the resistance activity to stress [58,59]. RLWC reflects the ability of plant leaves to maintain water balance, and the RLWC of plants with strong drought resistance would decrease with decreasing soil moisture in order to maintain normal physiological functioning of plants $[60,61]$. In this study, the RLWC of the two fern species showed a downward trend throughout the entire drought stress. The change of RLWC of the two fern species was slow between $31 \%$ and $5 \%$ of soil moisture, but decreased sharply at $2 \%$ of soil moisture. The results were similar to what was reported for Elymus elongates subsp. ponticus (Podp.) Melderis [62], Phragmites australis (Cav.) Trin. ex Steud. [63] and Leucaena leucocephala (Lam.) de Wit [60], indicating that the two fern species have the ability to maintain water content at the early stages of drought, but lost the ability at the late stages of drought [64,65]. Similar to the results of Deng et al. [66], the RLWC of the two fern species increased after rehydration. This change of RLWC indicates that the two fern species have the ability to resist drought to some extent. In addition, the RLWC of $A$. multidentatum was higher than $M$. 
struthiopteris throughout the drought stress, indicating that $A$. multidentatum has stronger ability to maintain water content.

SLA is an indicator of plant leaf thickness [67]. Previous studies suggested that the SLA decreased with drought stress, and the drought resistance of plants was negatively correlated with SLA [68]. However, we observed that the SLA increased slowly in general during exposure to drought stress but not significantly, which is similar to the observations by Díaz-Lòpez et al. [69] and Ludewing et al. [70]. Additionally, the SLA of $A$. multidentatum was higher than $M$. struthiopteris, suggesting that $A$. multidentatum has a stronger ability to accumulate more dry mass per unit leaf area than $M$. struthiopteris under drought stress [44].

\subsection{The Oxidative Damage of Drought Stress to the Two Fern Species}

As a ROS, $\mathrm{H}_{2} \mathrm{O}_{2}$ induces different degrees of damage to plant membrane lipids, proteins and DNA $[9,15,71]$. MDA is the end product of membrane lipid peroxidation, and its accumulation means that plant cells have high levels of lipid peroxides [9,72-74]. Membrane lipid peroxidation causes ion leakage by breaking the permselectivity of membranes [75]. The $\mathrm{H}_{2} \mathrm{O}_{2}$ and MDA content of Vitis vinifera L. [9], Amaranthus tricolor L. [44], Achillea species [76], Scutellaria baicalensis Georgi [6] and Cucumis sativus L. [77] increased under drought stress. In our experiment, the $\mathrm{H}_{2} \mathrm{O}_{2}$ content of $M$. struthiopteris increased, while the $\mathrm{H}_{2} \mathrm{O}_{2}$ content of $A$. multidentatum did not increase like $M$. struthiopteris, which means $M$. struthiopteris is more sensitive to drought stress than A. multidentatum. However, the MDA content of the two fern species increased during exposure to drought and then decreased after rehydration, which reflected that the two fern species suffered from severe lipid peroxidation under drought. However, the MDA content of $M$. struthiopteris changed immediately, indicating M. struthiopteris is more sensitive to drought stress [6,44,78,79]. Enhanced IL is regarded to be the sign of destruction of the membrane under water deficit $[44,75,78]$. In this research, IL increased remarkably with the drought exposure. This indicates that the membrane has been damaged and reflects the increase in MDA and $\mathrm{H}_{2} \mathrm{O}_{2}$ content $[44,80,81]$.

\subsection{The Regulation of Osmotic Regulators to Drought Stress}

SP and Pro are important osmotic regulators, which can reduce the water potential of plant cells and maintain tissue moisture to make plants perform normal physiological function. Additionally, Pro also improves the micro-environment in plant tissues [82]. Research on drought stress indicated that plants would accumulate SP and Pro when exposed to drought stress $[6,9,44]$, but some studies showed a different trend $[10,83]$. Similar to the results of Li et al. [10], in our research, the content of SP in two fern species increased rapidly after exposure to drought stress, indicating that plants accumulate SP immediately to regulate water content [44]. After rehydration, the SP content increased again, which means rehydration was helpful to protein synthesis after drought stress [83]. Although, the change in Pro content was lagging behind, probably because it is not suitable for the water regulation in rapid short-term drought [10].

ABA plays an important role in the response of plants to abiotic stress, such as drought stress and high temperature stress [84,85]. ABA stimulates short-term responses such as stomatal closure, so as to regulate water balance and plants growth under osmotic stress [86-88]. Studies have shown that the ABA content increases sharply under drought stress to help plants maintain water status $[86,89]$. In our study, the ABA content of $M$. struthiopteris showed a downward trend throughout the exposure to drought stress, but the ABA content of $A$. multidentatum maintained at a relative stable high level. In addition, the ABA content of the two fern species is negatively correlated with $\mathrm{H}_{2} \mathrm{O}_{2}$ content and IL $(\mathrm{r}=-0.52$ and $0.49, p \leq 0.01$, Supplementary Table S1), suggesting that the two fern species can enhance drought tolerance by increased ABA content $[15,90]$. Furthermore, the ABA content of $A$. multidentatum was higher than $M$. struthiopteris, which indicates that $A$. multidentatum has higher drought resistance by synthesizing $\mathrm{ABA}$ in time to regulate the physiological functions under drought stress. 


\subsection{The Effects of the Antioxidant System}

Plants' antioxidant systems include an enzymatic antioxidant system and non-enzymatic antioxidant system $[6,17,91]$. The non-enzymatic antioxidant system contains some secondary metabolites such as glutathione, ascorbic acid, phenols, flavonoids [92,93]. Flavonoids not only interact directly with ROS, but also serve as substrates for different peroxidases [94,95]. Similarly, phenols play an important role in the mitigation of oxidative stress, because they are related to the ROS scavenging [50,96]. Many studies showed that plants would accumulate flavonoids and phenols with decreasing soil moisture, such as Chrysanthemum morifolium L. [97], Gapsicum species [50], Citrus species [98] and Achillea species [76]. High levels of phenols and flavonoids in plants under drought stress means that the plants adapt to the drought environment [99]. In agreement with this, the two fern species had high levels of FC and TPC under drought exposure, which reflected that the two fern species adapt to drought stress by scavenging ROS by FC and TPC $[50,100]$. In addition, the FC and TPC are positively correlated with MDA content $(\mathrm{r}=0.54$ and $0.50, p \leq 0.01$, Supplementary Table S1). This may indicate that flavonoids and phenols are involved in the repair of membrane lipid peroxidation. However, the FC and TPC of M. struthiopteris are generally lower than that of $A$. multidentatum, reflecting the inherently higher non-enzymatic antioxidant system of $A$. multidentatum.

Proantho cyanidins are secondary metabolites with antioxidant effects, and their accumulation is greatly regulated by the environment. The research about the secondary metabolites of Korean Pine (Pinus koraiensis Sieb. et Zucc.) under drought indicated that the PCC decreased under severe drought stress [45]. However, in our research, the PCC of two fern species increased at the early drought stage. Similarity, the PCC was positively correlated with MDA ( $\mathrm{r}=0.61, p \leq 0.01$, Supplementary Table S1), which indicates it can improve the drought tolerance of the two fern species [45]. However, there was no significant difference in PCC between the two fern species in the early drought stage. In the late stages of drought, the higher PCC of $A$. multidentatum reflects the higher non-enzymatic antioxidant system of $A$. multidentatum.

The enzymatic antioxidant system of plants includes SOD, POD, CAT, APX and GR, acting as scavengers for ROS to protect plants from oxidative damage [101,102]. Some studies have shown that plants with stronger drought tolerance have a stronger antioxidant system, which enables plants maintain the dynamic balance of ROS under drought stress [103]. In our research, although the SOD, POD, CAT and APX activity of the two fern species changed differently, the antioxidant system could respond to drought to reduce ROS accumulation and maintain the stability of the membrane over time [15]. However, the SOD activity of the two fern species and CAT activity of M. struthiopteris decreased at the late stages of drought, which are consistent with the findings of Ju et al. [9] and Ji et al. [104], probably because the antioxidant system was impaired under severe drought stress $[9,10,99,105,106]$. The POD and CAT activity of $A$. multidentatum increased rapidly for drought stress, while the POD activity of $M$. struthiopteris changed slowly, indicating that $A$. multidentatum activates the POD and CAT rapidly to scavenge $\mathrm{H}_{2} \mathrm{O}_{2}[10,16,107]$.

\section{Conclusions}

In the present study, the drought resistance of two fern species in Northeast China was compared based on growth traits, secondary metabolites and enzyme activities. The two fern species displayed stronger drought resistance features at the early stages of drought. In addition, the growth, osmotic regulators and antioxidant system reacted immediately to drought stress. However, in the late stages of drought, the two fern species did not express stronger drought resistance. A. multidentatum showed higher drought resistance, mainly expressed as higher ABA content and non-enzymatic antioxidant system. In addition, our results suggested that secondary metabolites may play a preponderant role in the two fern species in drought resistance. Future studies may rely on these results to further study the relationship between secondary metabolites and drought resistance of fern species. 
Supplementary Materials: The following are available online at http:/ /www.mdpi.com/2073-4395/9/3/137/s1, Table S1: Correlations among the measured parameters in the experiments.

Author Contributions: Y.W., W.C. and X.H. conceived the study; Y.W. and S.G. performed the experiment; Y.L., P.L. and Y.Z. contributed reagents and materials; Y.W. and S.G. analyzed the data; Y.W. led the writing of the paper with substantial input from all co-authors.

Funding: The Technology and Demonstration of Ecological Protection and Exploitation and Utilization of Biological Resources in Northeast Forest Region: 2016YFC0500306. Construction of China Botanical Garden Alliance, Key Project of Chinese Academy of Sciences: KFJ-3W-No1. Chinese Academy of Sciences Science and Technology Resources Popularization Capacity Building: F16-191-5-00.

Acknowledgments: We would like to thank many students who provided a lot of help for the progress of this experiment. W.D. Xu, D.L. Tao and S. Xu from the Institute of Applied Ecology (CAS) provided highly useful edits on the revision of this paper. We would like to express our sincere thanks to the reviewers and editors for the constructive and positive comments, which have greatly improved the quality of this paper.

Conflicts of Interest: The authors declare no conflict of interest.

\section{References}

1. Zhang, X.; Liu, X.; Wang, W.; Zhang, T.; Zeng, X.; Xu, G.; Wu, G.; Kang, H. Spatiotemporal variability of drought in the northern part of Northeast China. Hydrol. Process. 2018, 32, 1449-1460. [CrossRef]

2. Mishra, A.K.; Singh, V.P. A review of drought concepts. J. Hydrol. 2010, 391, 204-216. [CrossRef]

3. Li, M.; Hu, W.; Zhang, L.; Wang, G.; Chai, X. Risk analysis of meteorological drought in Northeast China based on standardized precipitation evapotranspiration index. J. Arid. Land Resour. Environ. 2018, $134-139$. [CrossRef]

4. Cai, S.; Zuo, D.; Xu, Z.; Yang, X. Spatiotemporal characteristics of drought in Northeast China based on SPEI. South-North Water Transf. Water Sci. Technol. 2017, 15, 15-21. [CrossRef]

5. Shen, G.; Zhen, H.; Lei, Z. Spatiotemporal analysis of meteorological drought (1961-2014) in Northeast China using a standardized precipitation evaptranspiration index. Acta Ecol. Sin. 2017, 37, 5882-5893. [CrossRef]

6. Cheng, L.; Han, M.; Yang, L.-M.; Yang, L.; Sun, Z.; Zhang, T. Changes in the physiological characteristics and baicalin biosynthesis metabolism of Scutellaria baicalensis Georgi under drought stress. Ind. Crop. Prod. 2018, 122, 473-482. [CrossRef]

7. Selmar, D.; Kleinwächter, M. Influencing the product quality by deliberately applying drought stress during the cultivation of medicinal plants. Ind. Crop. Prod. 2013, 42, 558-566. [CrossRef]

8. Catola, S.; Marino, G.; Emiliani, G.; Huseynova, T.; Musayev, M.; Akparov, Z.; Maserti, B.E. Physiological and metabolomic analysis of Punica granatum (L.) under drought stress. Planta 2016, 243, 441-449. [CrossRef]

9. Ju, Y.-L.; Yue, X.-F.; Zhao, X.-f.; Zhao, H.; Fang, Y.-1. Physiological, micro-morphological and metabolomic analysis of grapevine (Vitis vinifera L.) leaf of plants under water stress. Plant Physiol. Biochem. 2018, 130, 501-510. [CrossRef]

10. Li, L.; Liu, Y.; Liu, Y.; He, B.; Wang, M.; Yu, C.; Weng, M. Physiological response and resistance of three cultivars of Acer rubrum L. to continuous drought stress. Acta Ecol. Sin. 2015, 35, 196-202. [CrossRef]

11. Per, T.S.; Khan, N.A.; Reddy, P.S.; Masood, A.; Hasanuzzaman, M.; Khan, M.I.R.; Anjum, N.A. Approaches in modulating proline metabolism in plants for salt and drought stress tolerance: Phytohormones, mineral nutrients and transgenics. Plant Physiol. Biochem. 2017, 115, 126-140. [CrossRef] [PubMed]

12. Rahimi, Y.; Taleei, A.; Ranjbar, M. Long-term water deficit modulates antioxidant capacity of peppermint (Mentha piperita L.). Sci. Hortic. 2018, 237, 36-43. [CrossRef]

13. Khan, M.N.; Zhang, J.; Luo, T.; Liu, J.; Ni, F.; Rizwan, M.; Fahad, S.; Hu, L. Morpho-physiological and biochemical responses of tolerant and sensitive rapeseed cultivars to drought stress during early seedling growth stage. Acta Physiol. Plant. 2019, 41, 25. [CrossRef]

14. Oral, O.; Kutlu, T.; Aksoy, E.; Fıçıcıoğlu, C.; Uslu, H.; Tuğrul, S. The effects of oxidative stress on outcomes of assisted reproductive techniques. J. Assist. Reprod. Genet. 2006, 23, 81-85. [CrossRef] [PubMed]

15. Zhang, S.-h.; Xu, X.-f.; Sun, Y.-m.; Zhang, J.-l.; Li, C.-z. Influence of drought hardening on the resistance physiology of potato seedlings under drought stress. J. Integr. Agric. 2018, 17, 336-347. [CrossRef]

16. Gill, S.S.; Tuteja, N. Reactive oxygen species and antioxidant machinery in abiotic stress tolerance in crop plants. Plant Physiol. Biochem. 2010, 48, 909-930. [CrossRef] [PubMed] 
17. Bozin, B.; Mimica-Dukic, N.; Samojlik, I.; Goran, A.; Igic, R. Phenolics as antioxidants in garlic (Allium sativum L. Alliaceae). Food Chem. 2008, 111, 925-929. [CrossRef]

18. Mackova, J.; Vaskova, M.; Macek, P.; Hronkova, M.; Schreiber, L.; Santrucek, J. Plant response to drought stress simulated by ABA application: Changes in chemical composition of cuticular waxes. Environ. Exp. Bot. 2013, 86, 70-75. [CrossRef]

19. Ren, F.; Zhang, R.; Chen, Q.; Bai, Y.; Huang, F.; Li, X. Progress in ABA and SA improving plant drought resistance and salt resistance. Biotechnol. Bull. 2012, 17-21. [CrossRef]

20. Liu, F.L.; Jensen, C.R.; Shahanzari, A.; Andersen, M.N.; Jacobsen, S.E. ABA regulated stomatal control and photosynthetic water use efficiency of potato (Solanum tuberosum L.) during progressive soil drying. Plant Sci. 2005, 168, 831-836. [CrossRef]

21. Ban, S.G.; Selak, G.V.; Leskovar, D.I. Short- and long-term responses of pepper seedlings to ABA exposure. Sci. Hortic. 2017, 225, 243-251. [CrossRef]

22. Wang, Y.; Ma, F.; Li, M.; Liang, D.; Zou, J. Physiological responses of kiwifruit plants to exogenous ABA under drought conditions. Plant Growth Regul. 2011, 64, 63-74. [CrossRef]

23. Liao, J.-X.; Jiang, M.-X.; Huang, H.-D. Growth characteristics of Adiantum reniforme var. sinensis and A-capillus-veneris in response to light and soil moisture. Nord. J. Bot. 2013, 31, 500-504. [CrossRef]

24. Liao, J.X.; Zhang, H.; Mo, L.; Huang, Y.Q.; Sun, Y.J.; Li, Y.Q. Differences in growth and biomass allocation of Adiantum flabellulatum and A. capillus-veneris as a result of light and water availability. Bot. Lett. 2017, 164, 393-400. [CrossRef]

25. Nishida, K.; Hanba, Y.T. Photosynthetic response of four fern species from different habitats to drought stress: Relationship between morpho-anatomical and physiological traits. Photosynthetica 2017, 55, 689-697. [CrossRef]

26. Wu, Y.C.; He, Y.J.; Gao, J. Drought tolerance of three kinds of wild ornamental ferns. Hubei For. Sci. Technol. 2015, 44, 17-21.

27. Li, Q.J.; Zhong, Q.Y.; Shao, L.; Ji, H.; Chen, L.Q. Effect of PEG stress on drought resistance physiological indices of two ferns' prothallus. Chin. Agric. Sci. Bull. 2014, 30, 155-160.

28. Sun, H.; Wang, Q.; Guan, Y.; Liu, B.D. Effects of Microlepia strigosa under drought stress on physiological change laws. Plant Sci. J. 2013, 31, 576-582. [CrossRef]

29. Dong, Y.L.; Chang, Y. Effects of drought stress on chlorophyll fluorescence characteristics of five species of ornamental ferns. North. Hortic. 2013, 15, 66-69.

30. Zhu, L.-J.; Yan, F.; Chen, J.-P.; Zhang, N.; Zhang, X.; Yao, X.-S. 8-O-4' Neolignan glycosides from the aerial parts of Matteuccia struthiopteris. Chin. Chem. Lett. 2016, 27, 63-65. [CrossRef]

31. Han, X.-Z.; Ma, R.; Chen, Q.; Jin, X.; Jin, Y.-Z.; An, R.-B.; Piao, X.-M.; Lian, M.-L.; Quan, L.-H.; Jiang, J. Anti-inflammatory action of Athyrium multidentatum extract suppresses the LPS-induced TLR4 signaling pathway. J. Ethnopharmacol. 2018, 217, 220-227. [CrossRef] [PubMed]

32. Fu, P. Clavis Plantarum Chinae Boreali-Orientalis; Science Press: Beijing, China, 1995; pp. 35-46.

33. Qi, G.; Yang, L.; Xiao, C.; Shi, J.; Mi, Y.; Liu, X. Nutrient values and bioactivities of the extracts from three fern species in China: A comparative assessment. Food Funct. 2015, 6, 2918-2929. [CrossRef]

34. Xu, J.; Wei, L.; Xu, H.; Gao, D. Effects of different ecological factors on growth and photosynthetic characteristics of Matteuccia struthiopteris. Chin. Agric. Sci. Bull. 2017, 33, 19-24.

35. Zhang, Y.; Yang, L. Investigation on Athyrium multidentatum (Doll.) Ching in different habitats. Chin. Wild Plant Resour. 2011, 30, 5-8.

36. Xiao, Q.; Ye, W.; Zhu, Z.; Chen, Y.; Zhen, H. A simple non-destructive method to measure leaf area using digital camera and Photoshop software. Chin. J. Ecol. 2005, 711-714. [CrossRef]

37. Li, X.Y.; Liu, G.S.; Yang, Y.F.; Zhao, C.H.; Yu, Q.W.; Song, S.X. Relationship between hyperspectral parameters and physiological and biochemical indexes of flue-cured tobacco leaves. Agric. Sci. China 2007, 665-672. [CrossRef]

38. Mukherjee, S.P.; Choudhuri, M.A. Implication of hydrogen peroxide-ascorbate system on membrane permeability of water stressed Vigna seedlings. New Phytol. 1985, 99, 355-360. [CrossRef]

39. Heath, R.L.; Packer, L. Photoperoxidation in isolated chloroplasts: I. Kinetics and stoichiometry of fatty acid peroxidation. Arch. Biochem. Biophys. 1968, 125, 189-198. [CrossRef]

40. Liu, J.J.; Wei, Z.; Li, J.H. Effects of copper on leaf membrane structure and root activity of maize seedling. Bot. Stud. 2014, 55. [CrossRef] [PubMed] 
41. Bradford, M.M. A rapid and sensitive method for the quantitation of microgram quantities of protein utilizing the principle of protein-dye binding. Anal. Biochem. 1976, 72, 248-254. [CrossRef]

42. Irigoyen, J.J.; Emerich, D.W.; Sanchezdiaz, M. Water-stress induced changes in concentrations of proline and total soluble sugars in Nodulated Alfalfa (Medicag0-astiva) plants. Physiol. Plant. 1992, 84, 55-60. [CrossRef]

43. Ali, A.; Ong, M.K.; Forney, C.F. Effect of ozone pre-conditioning on quality and antioxidant capacity of papaya fruit during ambient storage. Food Chem. 2014, 142, 19-26. [CrossRef]

44. Sarker, U.; Oba, S. Drought Stress Effects on Growth, ROS Markers, Compatible Solutes, Phenolics, Flavonoids, and Antioxidant Activity in Amaranthus tricolor. Appl. Biochem. Biotechnol. 2018, 186, 999-1016. [CrossRef]

45. Zhang, D.; Ren, J.; Liu, H.M.; Wang, H.M. Responses of main secondary metabolites and DPPH free radical scavenging activity of the Korean Pine to drought stress. Bull. Bot. Res. 2016, 36, 542-548.

46. Azevedo, R.A.; Alas, R.M.; Smith, R.J.; Lea, P.J. Response of antioxidant enzymes to transfer from elevated carbon dioxide to air and ozone fumigation, in the leaves and roots of wild-type and a catalase-deficient mutant of barley. Physiol. Plant. 1998, 104, 280-292. [CrossRef]

47. Zhou, W.; Leul, M. Uniconazole-induced tolerance of rape plants to heat stress in relation to changes in hormonal levels, enzyme activities and lipid peroxidation. Plant Growth Regul. 1999, 27, 99-104. [CrossRef]

48. Giannopolitis, C.N.; Ries, S.K. Superoxide dismutases: II. Purification and quantitative relationship with water-soluble protein in seedlings. Plant Physiol. 1977, 59, 315-318. [CrossRef]

49. Nakano, Y.; Asada, K. Hydrogen Peroxide is Scavenged by Ascorbate-specific peroxidase in Spinach chloroplasts. Plant Cell Physiol. 1981, 22, 867-880. [CrossRef]

50. Okunlola, G.O.; Olatunji, O.A.; Akinwale, R.O.; Tariq, A.; Adelusi, A.A. Physiological response of the three most cultivated pepper species (Capsicum spp.) in Africa to drought stress imposed at three stages of growth and development. Sci. Hortic. 2017, 224, 198-205. [CrossRef]

51. Hasan, M.M.-U.; Ma, F.; Prodhan, Z.H.; Li, F.; Shen, H.; Chen, Y.; Wang, X. Molecular and physio-biochemical characterization of cotton species for assessing drought stress tolerance. Int. J. Mol. Sci. 2018, 19, 2636. [CrossRef]

52. Ravikumar, G.; Manimaran, P.; Voleti, S.R.; Subrahmanyam, D.; Sundaram, R.M.; Bansal, K.C.; Viraktamath, B.C.; Balachandran, S.M. Stress-inducible expression of AtDREB1A transcription factor greatly improves drought stress tolerance in transgenic indica rice. Transgenic Res. 2014, 23, 421-439. [CrossRef] [PubMed]

53. Dossa, K.; Yehouessi, L.W.; Likeng-Li-Ngue, B.C.; Diouf, D.; Liao, B.S.; Zhang, X.R.; Cisse, N.; Bell, J.M. Comprehensive screening of some west and central African sesame genotypes for drought resistance probing by agromorphological, physiological, biochemical and seed quality traits. Agronomy 2017, 7, 83. [CrossRef]

54. Budak, H.; Kantar, M.; Kurtoglu, K.Y. Drought tolerance in modern and wild wheat. Sci. World J. 2013, 2013, 548246. [CrossRef] [PubMed]

55. Gao, D.W.; Sun, X.W.; Li, R.X.; Liu, G. The investigate and analyze in habitat of Matteuccia struthiopteris Todaro. Territ. Nat. Resour. Study 2007, 92-93.

56. Ghalambor, C.K.; McKay, J.K.; Carroll, S.P.; Reznick, D.N. Adaptive versus non-adaptive phenotypic plasticity and the potential for contemporary adaptation in new environments. Funct. Ecol. 2007, 21, $394-407$. [CrossRef]

57. Auslander, M.; Nevo, E.; Inbar, M. The effects of slope orientation on plant growth, developmental instability and susceptibility to herbivores. J. Arid Environ. 2003, 55, 405-416. [CrossRef]

58. Bongers, F.J.; Olmo, M.; Lopez-Iglesias, B.; Anten, N.P.R.; Villar, R. Drought responses, phenotypic plasticity and survival of Mediterranean species in two different microclimatic sites. Plant Biol. 2017, 19, 386-395. [CrossRef] [PubMed]

59. Lortie, C.J.; Aarssen, L.W. The specialization hypothesis for phenotypic plasticity in plants. Int. J. Plant Sci. 1996, 157, 484-487. [CrossRef]

60. Chen, Y.; Chen, F.; Liu, L.; Zhu, S. Physiological responses of Leucaena leucocephala seedlings to drought stress. In Proceedings of the 2012 International Conference on Modern Hydraulic Engineering, Nanjing, China, 9-11 March 2012; Zhou, B., Ed.; Elsevier: Amsterdam, The Netherlands, 2012. [CrossRef]

61. Marshall, J.G.; Rutledge, R.G.; Blumwald, E.; Dumbroff, E.B. Reduction in turgid water volume in jack pine, white spruce and black spruce in response to drought and paclobutrazol. Tree Physiol. 2000, 20, 701-707. [CrossRef] 
62. Borrajo, C.I.; Sanchez-Moreiras, A.M.; Reigosa, M.J. Morpho-physiological responses of tall wheatgrass populations to different levels of water stress. PLoS ONE 2018, 13, e0209281. [CrossRef]

63. Pagter, M.; Bragato, C.; Brix, H. Tolerance and physiological responses of Phragmites australis to water deficit. Aquat. Bot. 2005, 81, 285-299. [CrossRef]

64. Meher; Shivakrishna, P.; Ashok Reddy, K.; Manohar Rao, D. Effect of PEG-6000 imposed drought stress on RNA content, relative water content (RWC), and chlorophyll content in peanut leaves and roots. Saudi J. Biol. Sci. 2018, 25, 285-289. [CrossRef]

65. Bayoumi, T.Y.; Eid, M.H.; Metwali, E.M. Application of physiological and biochemical indices as a screening technique for drought tolerance in wheat genotypes. Afr. J. Biotechnol. 2008, 7, 2341-2352. [CrossRef]

66. Deng, H.M.; Long, C.Y.; Cai, S.Z.; Song, Y.; Yan, R.X.; Che, Y.R.; Wang, C.J.; Xiao, Y. Morphology and physiological characteristics of Stachys lanata seedling under water stress. Acta Bot. Boreali-Occident. Sin. 2018, 38, 1099-1108. [CrossRef]

67. Lichtenthaler, H.K.; Ač, A.; Marek, M.V.; Kalina, J.; Urban, O. Differences in pigment composition, photosynthetic rates and chlorophyll fluorescence images of sun and shade leaves of four tree species. Plant Physiol. Biochem. 2007, 45, 577-588. [CrossRef]

68. Lindsey, A.J.; Barker, D.J.; Metzger, J.D.; Mullen, R.W.; Thomison, P.R. Physiological and morphological response of a drought-tolerant maize hybrid to agronomic management. Agron. J. 2018, 110, 1354-1362. [CrossRef]

69. Diaz-Lopez, L.; Gimeno, V.; Simon, I.; Martinez, V.; Rodriguez-Ortega, W.M.; Garcia-Sanchez, F. Jatropha curcas seedlings show a water conservation strategy under drought conditions based on decreasing leaf growth and stomatal conductance. Agric. Water Manag. 2012, 105, 48-56. [CrossRef]

70. Ludewig, K.; Hanke, J.M.; Wuthe, B.; Otte, A.; Mosner, E.; Eckstein, R.L.; Donath, T.W. Differential effect of drought regimes on the seedling performance of six floodplain grassland species. Plant Biol. 2018, 20, 691-697. [CrossRef] [PubMed]

71. Foyer, C.H.; Noctor, G. Redox regulation in photosynthetic organisms: Signaling, acclimation, and practical implications. Antioxid. Redox Signal. 2009, 11, 861-905. [CrossRef]

72. Upadhyaya, H.; Khan, M.H.; Panda, S.K. Hydrogen peroxide induces oxidative stress in detached leaves of Oryza sativa L. Plant Physiol. 2006, 33, 83-95.

73. Zhao, H.-J.; Tan, J.-F. Role of calcium ion in protection against heat and high irradiance stress-induced oxidative damage to photosynthesis of wheat leaves. Photosynthetica 2005, 43, 473-476. [CrossRef]

74. Liu, R.; Shi, H.; Wang, Y.; Chen, S.; Deng, J.; Liu, Y.; Li, S.; Chan, Z. Comparative physiological analysis of lotus (Nelumbo nucifera) cultivars in response to salt stress and cloning of NnCIPK genes. Sci. Hortic. 2014, 173, 29-36. [CrossRef]

75. Chai, Y.; Zhang, S.; Yao, C. Effects of drought stress and rewatering on photosynthetic physiological characteristics of sorghum. In Proceedings of the IEEE 2011 International Conference on Remote Sensing, Environment and Transportation Engineering, Nanjing, China, June 2011. [CrossRef]

76. Gharibi, S.; Tabatabaei, B.E.S.; Saeidi, G.; Goli, S.A.H. Effect of drought stress on total phenolic, lipid peroxidation, and antioxidant activity of Achillea species. Appl. Biochem. Biotechnol. 2016, 178, 796-809. [CrossRef]

77. Nie, W.; Gong, B.; Chen, Y.; Wang, J.; Wei, M.; Shi, Q. Photosynthetic capacity, ion homeostasis and reactive oxygen metabolism were involved in exogenous salicylic acid increasing cucumber seedlings tolerance to alkaline stress. Sci. Hortic. 2018, 235, 413-423. [CrossRef]

78. Jin, R.; Shi, H.; Han, C.; Zhong, B.; Wang, Q.; Chan, Z. Physiological changes of purslane (Portulaca oleracea L.) after progressive drought stress and rehydration. Sci. Hortic. 2015, 194, 215-221. [CrossRef]

79. Filippou, P.; Antoniou, C.; Fotopoulos, V. Effect of drought and rewatering on the cellular status and antioxidant response of Medicago truncatula plants. Plant Signal. Behav. 2011, 6, 270-277. [CrossRef]

80. Sahin, U.; Ekinci, M.; Ors, S.; Turan, M.; Yildiz, S.; Yildirim, E. Effects of individual and combined effects of salinity and drought on physiological, nutritional and biochemical properties of cabbage (Brassica oleracea var. capitata). Sci. Hortic. 2018, 240, 196-204. [CrossRef]

81. Ekinci, M.; Ors, S.; Sahin, U.; Yildirim, E.; Dursun, A. Responses to the irrigation water amount of spinach supplemented with organic amendment in greenhouse conditions. Commun. Soil Sci. Plant Anal. 2015, 46, 327-342. [CrossRef] 
82. Anamul Hoque, M.; Okuma, E.; Nasrin Akhter Banu, M.; Nakamura, Y.; Shimoishi, Y.; Murata, Y. Exogenous proline mitigates the detrimental effects of salt stress more than exogenous betaine by increasing antioxidant enzyme activities. J. Plant Physiol. 2007, 164, 553-561. [CrossRef] [PubMed]

83. Wu, X.; Yuan, J.; Luo, A.; Chen, Y.; Fan, Y. Drought stress and re-watering increase secondary metabolites and enzyme activity in dendrobium moniliforme. Ind. Crop. Prod. 2016, 94, 385-393. [CrossRef]

84. Sauter, A.; Davies, W.J.; Hartung, W. The long-distance abscisic acid signal in the droughted plant: The fate of the hormone on its way from root to shoot. J. Exp. Bot. 2001, 52, 1991-1997. [CrossRef] [PubMed]

85. Finkelstein, R.R.; Gampala, S.S.L.; Rock, C.D. Abscisic acid signaling in seeds and seedlings. Plant Cell 2002, 14 (Suppl. 1), S15-S45. [CrossRef]

86. Dar, N.A.; Amin, I.; Wani, W.; Wani, S.A.; Shikari, A.B.; Wani, S.H.; Masoodi, K.Z. Abscisic acid: A key regulator of abiotic stress tolerance in plants. Plant Gene 2017, 11, 106-111. [CrossRef]

87. Koffler, B.E.; Luschin-Ebengreuth, N.; Stabentheiner, E.; Mueller, M.; Zechmann, B. Compartment specific response of antioxidants to drought stress in Arabidopsis. Plant Sci. 2014, 227, 133-144. [CrossRef] [PubMed]

88. Sah, S.K.; Reddy, K.R.; Li, J. Abscisic Acid and Abiotic Stress Tolerance in Crop Plants. Front. Plant Sci. 2016, 7, 571. [CrossRef] [PubMed]

89. Zhang, S.; Chen, F.G.; Peng, S.M.; Ma, W.J.; Korpelainen, H.; Li, C.Y. Comparative physiological, ultrastructural and proteomic analyses reveal sexual differences in the responses of Populus cathayana under drought stress. Proteomics 2010, 10, 2661-2677. [CrossRef] [PubMed]

90. Pavlovic, I.; Petrik, I.; Tarkowska, D.; Lepedus, H.; Vujcic Bok, V.; Radic Brkanac, S.; Novak, O.; Salopek-Sondi, B. Correlations between phytohormones and drought tolerance in selected Brassica crops: Chinese cabbage, white cabbage and kale. Int. J. Mol. Sci. 2018, 19, 2866. [CrossRef] [PubMed]

91. Soares, C.; Carvalho, M.E.A.; Azevedo, R.A.; Fidalgo, F. Plants facing oxidative challenges-A little help from the antioxidant networks. Environ. Exp. Bot. 2018. [CrossRef]

92. Mittler, R. ROS Are Good. Trends Plant Sci. 2017, 22, 11-19. [CrossRef]

93. Amaral Carvalho, M.E.; Piotto, F.A.; Franco, M.R.; Reis Borges, K.L.; Gaziola, S.A.; Camargo Castro, P.R.; Azevedo, R.A. Cadmium toxicity degree on tomato development is associated with disbalances in B and Mn status at early stages of plant exposure. Ecotoxicology 2018, 27, 1293-1302. [CrossRef]

94. Pourcel, L.; Routaboul, J.-M.; Cheynier, V.; Lepiniec, L.; Debeaujon, I. Flavonoid oxidation in plants: From biochemical properties to physiological functions. Trends Plant Sci. 2007, 12, 29-36. [CrossRef] [PubMed]

95. Hernandez, I.; Alegre, L.; Van Breusegem, F.; Munne-Bosch, S. How relevant are flavonoids as antioxidants in plants? Trends Plant Sci. 2009, 14, 125-132. [CrossRef]

96. Wang, C.; Lu, J.; Zhang, S.; Wang, P.; Hou, J.; Qian, J. Effects of Pb stress on nutrient uptake and secondary metabolism in submerged macrophyte Vallisneria natans. Ecotoxicol. Environ. Saf. 2011, 74, 1297-1303. [CrossRef] [PubMed]

97. Hodaei, M.; Rahimmalek, M.; Arzani, A.; Talebi, M. The effect of water stress on phytochemical accumulation, bioactive compounds and expression of key genes involved in flavonoid biosynthesis in Chrysanthemum morifolium L. Ind. Crop. Prod. 2018, 120, 295-304. [CrossRef]

98. Dos Santos, I.C.; de Almeida, A.-A.F.; Pirovani, C.P.; Costa, M.G.C.; das Gracas Fernandes da Silva, M.F.; Bellete, B.S.; Freschi, L.; Soares Filho, W.; Coelho Filho, M.A.; Gesteira, A.d.S. Differential accumulation of flavonoids and phytohormones resulting from the canopy/rootstock interaction of citrus plants subjected to dehydration/rehydration. Plant Physiol. Biochem. 2017, 119, 147-158. [CrossRef] [PubMed]

99. Liu, H.; Wang, X.; Wang, D.; Zou, Z.; Liang, Z. Effect of drought stress on growth and accumulation of active constituents in Salvia miltiorrhiza Bunge. Ind. Crop. Prod. 2011, 33, 84-88. [CrossRef]

100. de Abreu, I.N.; Mazzafera, P. Effect of water and temperature stress on the content of active constituents of Hypericum brasiliense Choisy. Plant Physiol. Biochem. 2005, 43, 241-248. [CrossRef] [PubMed]

101. Fang, Y.; Xiong, L. General mechanisms of drought response and their application in drought resistance improvement in plants. Cell. Mol. Life Sci. 2015, 72, 673-689. [CrossRef] [PubMed]

102. Helaly, M.N.; El-Hoseiny, H.; El-Sheery, N.I.; Rastogi, A.; Kalaji, H.M. Regulation and physiological role of silicon in alleviating drought stress of mango. Plant Physiol. Biochem. 2017, 118, 31-44. [CrossRef]

103. Pang, J.; Hao, L.; Zhang, F.; Zhao, P.; Yang, Z. The response of active oxygen species and ascorbic acid in Pugionium cornutum (L.) Gaertn. leaves to drought stress. Plant Physiol. J. 2013, 49, 57-62. [CrossRef] 
104. Ji, Y.; Zhang, X.Q.; Peng, Y.; Liang, X.Y.; Huang, L.K.; Ma, X.; Ma, Y.M. Effects of drought stress on lipid peroxidation, osmotic adjustment and activities of protective enzymes in the roots and leaves of orchardgrass. Acta Prataculturae Sin. 2014, 23, 144-151. [CrossRef]

105. Chool Boo, Y.; Jung, J. Water Deficit-Induced oxidative stress and antioxidative defenses in rice plants. J. Plant Physiol. 1999, 155, 255-261. [CrossRef]

106. Liu, C.; Liu, Y.; Guo, K.; Fan, D.; Li, G.; Zheng, Y.; Yu, L.; Yang, R. Effect of drought on pigments, osmotic adjustment and antioxidant enzymes in six woody plant species in karst habitats of southwestern China. Environ. Exp. Bot. 2011, 71, 174-183. [CrossRef]

107. Weydert, C.J.; Cullen, J.J. Measurement of superoxide dismutase, catalase and glutathione peroxidase in cultured cells and tissue. Nat. Protoc. 2010, 5, 51-66. [CrossRef]

(C) 2019 by the authors. Licensee MDPI, Basel, Switzerland. This article is an open access article distributed under the terms and conditions of the Creative Commons Attribution (CC BY) license (http:/ / creativecommons.org/licenses/by/4.0/). 